\title{
PRKG1 wt Allele
}

National Cancer Institute

\section{Source}

National Cancer Institute. PRKG1 wt Allele. NCI Thesaurus. Code C125496.

Human PRKG1 wild-type allele is located in the vicinity of 10q11.2 and is approximately $1307 \mathrm{~kb}$ in length. This allele, which encodes cGMP-dependent protein kinase 1 protein, plays a role in both protein phosphorylation and nitric oxide signaling. Mutation of the gene is associated with familial thoracic aortic aneurysm type 8. 